\title{
Density Functional Theory Investigations on the Geometric and Electronic Structures of 4-Azidomethyl-6-Isopropyl-2H-Chromen-2-One
}

\author{
Pek-Lan Toh ${ }^{1, \text { a }}$, Montha Meepripruk ${ }^{2, \mathrm{~b}}$, Lee Sin Ang $^{3, \mathrm{c}}$, Shukri Sulaiman ${ }^{4, \mathrm{~d}}$ and Mohamed Ismail Mohamed-lbrahim ${ }^{4, \mathrm{e}}$ \\ ${ }^{1}$ Department of Electronic Engineering, Faculty of Engineering and Green Technology, Universiti Tunku Abdul Rahman, 31900 Perak, \\ Malaysia \\ ${ }^{2}$ School of Chemistry, Institute of Science and Technology, Kampheang Phet Rajabhat University, Kampheang Phet 62000, Thailand \\ ${ }^{3}$ Faculty of Applied Sciences, Universiti Teknologi Mara, 02600 Perlis, Malaysia \\ ${ }^{4}$ Computational Chemistry and Physics Laboratory, School of Distance Education, Universiti Sains Malaysia, 11800 Penang, Malaysia
}

\begin{abstract}
We have employed first principle Density Functional Theory (DFT) investigations to study the physical and electronic properties of 4-Azidomethyl-6-isopropyl-2H-chromen-2-one, C13H13N3O2. Complete geometry optimization calculations were carried out to find local energy minimum of the molecular system using the B3LYP approach with a variety of basis sets. The optimized geometries were then used to determine the HOMO-LUMO gaps, Mulliken atomic charges, and others. Our calculation results show that the computed geometrical properties of $\mathrm{C} 13 \mathrm{H} 13 \mathrm{~N} 3 \mathrm{O} 2$ cluster model are in good agreement with the corresponding measured experimental value. The calculated energies obtained are close to each other using the B3LYP density functional method combined with a variety of basis sets. Furthermore, using B3LYP/6-31G** method, the oxygen-attached carbon, $\mathrm{C} 2$ atom has the highest positively charge, with the corresponding value of +0.59 . For both oxygen atoms $(\mathrm{O} 1$ and $\mathrm{O} 2)$, the calculated charge values obtained are about -0.52 and -0.46 , respectively.
\end{abstract}

\section{Introduction}

In recent years, the substituted coumarin derivatives have been shown to possess great potential for usage in the fields of chemistry, polymer science, biology, medicine, and others [1-8]. A large number of experiment investigations $[7,8]$ have been carried out on the substituted coumarin derivatives, namely X-ray crystallography, IR, Raman spectroscopy, and others. For example, using IR and NMR techniques, Dekic et al. [8] studied the dynamic properties of new coumarin derivatives, which can be prepared by reaction of 4chloro-2-oxo-2H-chromene-3-carbonitrile with 4methyl-pyridin-2-ylamine and 6-methoxybenzothiazol-2-ylamine. In 2015, the new crystal structure of $\mathrm{C}_{13} \mathrm{H}_{13} \mathrm{~N}_{3} \mathrm{O}_{2}$ was determined by $\mathrm{X}$-ray crystallography method which investigated by Krishnamurthy et al. [7]. Furthermore, there have been a variety of theoretical studies $[3,6]$ on the substituted coumarin derivatives. First principle DFT simulation approach is one of the most popular computational tools for studying, predicting the geometric and electronic structures of the molecular systems nowadays $[6,9,10]$. In 2009, Subramanian et al. [6] employed the HartreeFock (HF) and DFT methods to investigate the geometric parameters, energies, and vibrational wave numbers of $7-$ amino-4-trifluoromethyl coumarin compound, respectively. As far as we know there are no computational studies in the literature of $\mathrm{C}_{13} \mathrm{H}_{13} \mathrm{~N}_{3} \mathrm{O}_{2}$ cluster model. In this study, based on the results obtained from first principle DFT calculations, we only focus on the geometric and electronic structures of $\mathrm{C}_{13} \mathrm{H}_{13} \mathrm{~N}_{3} \mathrm{O}_{2}$. The details of the computational methodology, results, discussion, and summary are provided in the following sections.

\section{Computational methodology}

All computational calculations were carried out with the Gaussian 09 program package [11] using first principle Density Functional Theory (DFT) simulation approach. In this investigation, a single molecule of $\mathrm{C}_{13} \mathrm{H}_{13} \mathrm{~N}_{3} \mathrm{O}_{2}$ was chosen to simulate the local host environment. Fig. 1 shows the atomic labelling of $\mathrm{C}_{13} \mathrm{H}_{13} \mathrm{~N}_{3} \mathrm{O}_{2}$ with the corresponding numbering scheme. Using the $\mathrm{C}_{13} \mathrm{H}_{13} \mathrm{~N}_{3} \mathrm{O}_{2}$ cluster model, geometry optimization calculations were performed to determine the local energy minimum of the molecular system with the B3LYP functional calculations employing with a variety of basis sets $\left(6-31 \mathrm{G}, 6-31++\mathrm{G}, 6-31 \mathrm{G}^{* *}, 6-\right.$ $31++\mathrm{G}^{* *}, 6-311 \mathrm{G}, \quad 6-311++\mathrm{G}, 6-311 \mathrm{G}^{* *}$, and $6-$ $\left.311++\mathrm{G}^{* *}\right)$. The corresponding optimized molecular geometries were then used to evaluate the HOMOLUMO gaps. In addition, single point calculations with the B3LYP/6-31G** level of theory were also performed

Corresponding author: ${ }^{\mathrm{a} p e k l a n}$ toh $@$ yahoo.com.my, ${ }^{\mathrm{b}}$ montha mee@ $@$ hotmail.com, ${ }^{\mathrm{c}}$ anglee631@perlis.uitm.edu.my,

dshukri@usm.my, ${ }^{\mathrm{d}}$ mi-mi@usm.my 
to predict the Mulliken atomic charges of the $\mathrm{C}_{13} \mathrm{H}_{13} \mathrm{~N}_{3} \mathrm{O}_{2}$ molecular cluster.

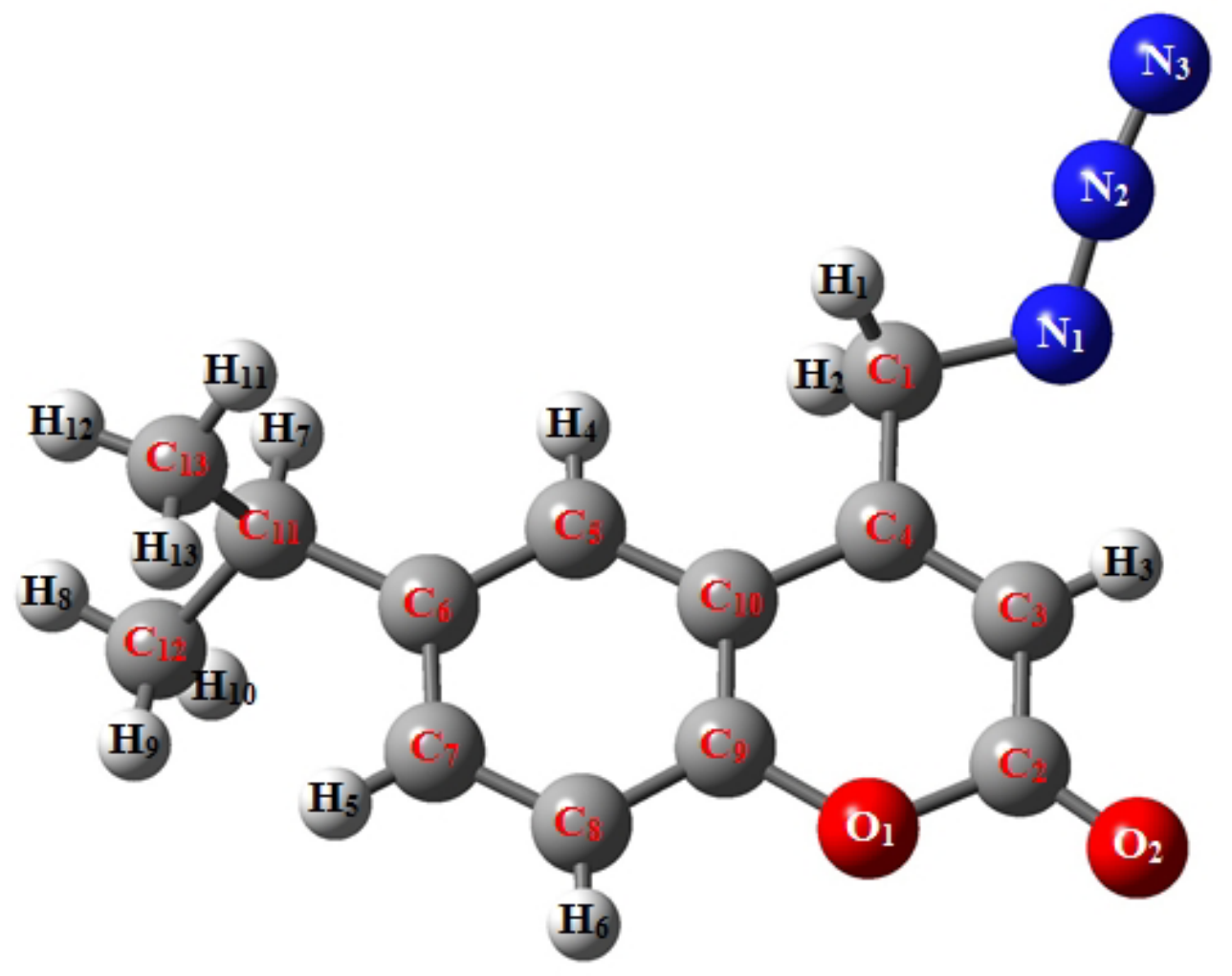

Fig. 1. The numbering system used for the $\mathrm{C} 13 \mathrm{H} 13 \mathrm{~N} 3 \mathrm{O} 2$ cluster model.

\section{Results and discussion}

For the molecular cluster of $\mathrm{C}_{13} \mathrm{H}_{13} \mathrm{~N}_{3} \mathrm{O}_{2}$, the optimized geometrical parameters (bond lengths, bond angles, and dihedral angles) are illustrated in Table 1. Compared with the experimental results, all the computed data are quite consistent with the experiment which presented by Subramanian et al. [8]. Furthermore, it can be clearly observed from the table that the calculated bond lengths in the case of B3LYP functional with 6$31 \mathrm{G}^{* *}, 6-31++\mathrm{G}^{* *}, 6-311 \mathrm{G}^{* *}$, and $6-311++\mathrm{G}^{* *}$ basis sets are the closest with those of experiment values. The corresponding bond values obtained are only different

Table 1. Optimized geometrical parameters of $\mathrm{C} 13 \mathrm{H} 13 \mathrm{~N} 3 \mathrm{O} 2$ cluster

\begin{tabular}{|c|c|c|c|c|c|c|c|c|c|}
\hline & $\begin{array}{c}6- \\
31 G \\
\end{array}$ & $\begin{array}{c}6- \\
31++G\end{array}$ & $\begin{array}{c}6- \\
31 G^{* *} \\
\end{array}$ & $\begin{array}{c}6- \\
31++G^{* *} \\
\end{array}$ & $\begin{array}{c}6- \\
311 G \\
\end{array}$ & $\begin{array}{c}6- \\
311++G \\
\end{array}$ & $\begin{array}{c}6- \\
311 G^{* *}\end{array}$ & $\begin{array}{c}6- \\
311++G^{* *} \\
\end{array}$ & $\begin{array}{c}\text { Experiment } \\
{[8]} \\
\end{array}$ \\
\hline \multicolumn{10}{|c|}{ Bond Length (Angstrom) } \\
\hline $\mathrm{N} 1-\mathrm{N} 2$ & 1.252 & 1.252 & 1.235 & 1.235 & 1.253 & 1.252 & 1.231 & 1.230 & 1.227 \\
\hline $\mathrm{N} 2-\mathrm{N} 3$ & 1.159 & 1.158 & 1.142 & 1.142 & 1.155 & 1.155 & 1.134 & 1.134 & 1.133 \\
\hline $\mathrm{C} 1-\mathrm{N} 1$ & 1.494 & 1.495 & 1.473 & 1.473 & 1.494 & 1.494 & 1.470 & 1.471 & 1.471 \\
\hline $\mathrm{C} 1-\mathrm{C} 4$ & 1.514 & 1.515 & 1.515 & 1.516 & 1.514 & 1.514 & 1.514 & 1.514 & 1.508 \\
\hline $\mathrm{C} 3-\mathrm{C} 4$ & 1.364 & 1.365 & 1.355 & 1.356 & 1.362 & 1.362 & 1.353 & 1.353 & 1.346 \\
\hline $\mathrm{C} 2-\mathrm{C} 3$ & 1.445 & 1.445 & 1.448 & 1.447 & 1.443 & 1.442 & 1.447 & 1.446 & 1.441 \\
\hline $\mathrm{C} 2-\mathrm{O} 2$ & 1.445 & 1.445 & 1.448 & 1.447 & 1.443 & 1.442 & 1.447 & 1.446 & 1.441 \\
\hline $\mathrm{C} 2-\mathrm{O} 1$ & 1.417 & 1.414 & 1.401 & 1.400 & 1.416 & 1.413 & 1.400 & 1.398 & 1.382 \\
\hline $\mathrm{C} 9-\mathrm{O} 1$ & 1.387 & 1.390 & 1.371 & 1.374 & 1.388 & 1.389 & 1.369 & 1.371 & 1.385 \\
\hline C9-C10 & 1.411 & 1.411 & 1.407 & 1.407 & 1.407 & 1.408 & 1.403 & 1.404 & 1.391 \\
\hline
\end{tabular}




\begin{tabular}{|c|c|c|c|c|c|c|c|c|c|}
\hline $\mathrm{C} 4-\mathrm{C} 10$ & 1.466 & 1.465 & 1.451 & 1.452 & 1.467 & 1.465 & 1.451 & 1.451 & 1.450 \\
\hline $\mathrm{C} 5-\mathrm{C} 10$ & 1.419 & 1.421 & 1.418 & 1.420 & 1.418 & 1.419 & 1.416 & 1.417 & 1.407 \\
\hline $\mathrm{C} 5-\mathrm{C} 6$ & 1.400 & 1.401 & 1.397 & 1.397 & 1.397 & 1.397 & 1.394 & 1.394 & 1.391 \\
\hline $\mathrm{C} 6-\mathrm{C} 7$ & 1.415 & 1.416 & 1.413 & 1.414 & 1.412 & 1.413 & 1.410 & 1.411 & 1.398 \\
\hline $\mathrm{C} 7-\mathrm{C} 8$ & 1.388 & 1.389 & 1.386 & 1.387 & 1.386 & 1.386 & 1.383 & 1.384 & 1.377 \\
\hline $\mathrm{C} 8-\mathrm{C} 9$ & 1.392 & 1.393 & 1.390 & 1.390 & 1.390 & 1.390 & 1.387 & 1.387 & 1.378 \\
\hline C6-C11 & 1.528 & 1.528 & 1.525 & 1.525 & 1.528 & 1.527 & 1.524 & 1.524 & 1.516 \\
\hline $\mathrm{C} 11-\mathrm{C} 12$ & 1.552 & 1.553 & 1.546 & 1.547 & 1.551 & 1.551 & 1.545 & 1.545 & 1.531 \\
\hline C11-C13 & 1.557 & 1.557 & 1.551 & 1.552 & 1.555 & 1.555 & 1.550 & 1.550 & 1.532 \\
\hline \multicolumn{10}{|c|}{ Bond Angle (Degree) } \\
\hline $\mathrm{C} 1-\mathrm{N} 1-\mathrm{N} 2$ & $\begin{array}{c}110.1 \\
4\end{array}$ & 110.18 & 110.03 & 110.12 & 110.07 & 110.08 & 109.92 & 109.96 & 109.92 \\
\hline $\mathrm{C} 4-\mathrm{C} 1-\mathrm{N} 1$ & $\begin{array}{c}121.3 \\
4\end{array}$ & 121.30 & 121.46 & 121.37 & 121.41 & 121.40 & 121.56 & 121.52 & 121.56 \\
\hline $\mathrm{C} 3-\mathrm{C} 2-\mathrm{O} 2$ & $\begin{array}{c}126.2 \\
0\end{array}$ & 126.20 & 126.20 & 126.20 & 126.20 & 126.20 & 126.20 & 126.20 & 126.20 \\
\hline $\mathrm{O} 1-\mathrm{C} 2-\mathrm{O} 2$ & $\begin{array}{c}117.0 \\
3\end{array}$ & 116.92 & 117.27 & 117.17 & 117.05 & 116.96 & 117.41 & 117.31 & 116.80 \\
\hline C5-C6-C11 & $\begin{array}{c}121.5 \\
0\end{array}$ & 121.44 & 121.41 & 121.35 & 121.49 & 121.44 & 121.40 & 121.36 & 121.27 \\
\hline C7-C6-C11 & $\begin{array}{c}119.9 \\
0\end{array}$ & 119.96 & 119.99 & 120.05 & 119.92 & 119.96 & 120.00 & 120.05 & 120.13 \\
\hline $\mathrm{C} 6-\mathrm{C} 11-\mathrm{C} 12$ & $\begin{array}{c}111.9 \\
0\end{array}$ & 111.88 & 111.85 & 111.82 & 111.90 & 111.88 & 111.84 & 111.82 & 111.80 \\
\hline $\mathrm{C} 6-\mathrm{C} 11-\mathrm{C} 13$ & $\begin{array}{c}111.1 \\
4\end{array}$ & 111.11 & 111.10 & 111.08 & 111.13 & 111.11 & 111.11 & 111.09 & 111.03 \\
\hline \multicolumn{10}{|c|}{ Dihedral Angle (Degree) } \\
\hline $\mathrm{N} 2-\mathrm{N} 1-\mathrm{C} 1-\mathrm{C} 4$ & 39.29 & 39.29 & 39.34 & 39.33 & 39.29 & 39.29 & 39.35 & 39.34 & 39.34 \\
\hline $\begin{array}{c}\mathrm{C} 5-\mathrm{C} 6-\mathrm{C} 11- \\
\mathrm{C} 13\end{array}$ & 70.68 & 70.66 & 70.65 & 70.62 & 70.68 & 70.66 & 70.65 & 70.63 & 70.58 \\
\hline $\begin{array}{c}\mathrm{C} 7-\mathrm{C} 6-\mathrm{C} 11- \\
\mathrm{C} 12 \\
\end{array}$ & $\begin{array}{c}126.0 \\
3 \\
\end{array}$ & 126.06 & 126.07 & 126.09 & 126.04 & 126.06 & 126.06 & 126.08 & 126.13 \\
\hline
\end{tabular}

with those of experimental data in the range of $0.1 \%-$ $1.4 \%$. As can see from the table, the bond length of $\mathrm{C}_{3}-$ $\mathrm{C}_{4}$ has the shortest value among the $\mathrm{C}-\mathrm{C}$ bonds in the $\mathrm{C}_{13} \mathrm{H}_{13} \mathrm{~N}_{3} \mathrm{O}_{2}$ cluster model, and the order of this $\mathrm{C}-\mathrm{C}$ bond is 2 . While the other bond lengths, namely $\mathrm{C}_{2}-\mathrm{C}_{3}$, $\mathrm{C}_{5}-\mathrm{C}_{6}, \mathrm{C}_{6}-\mathrm{C}_{7}, \mathrm{C}_{8}-\mathrm{C}_{9}, \mathrm{C}_{9}-\mathrm{C}_{10}$, and $\mathrm{C}_{5}-\mathrm{C}_{10}$ obtained are close to all $\mathrm{C}-\mathrm{C}$ values in organic benzene. These $\mathrm{C}-\mathrm{C}$ bonds have half a $\pi-$ bond and one $\sigma-$ bond. Yet, the bond orders for these $\mathrm{C}-\mathrm{C}$ bonds are then equal to 1.5 . For the case of the bond angles, the values obtained using B3LYP method with with a variety of basis sets are listed in Table 1. The calculated bond angles of $\mathrm{C}_{13} \mathrm{H}_{13} \mathrm{~N}_{3} \mathrm{O}_{2}$ cluster are in close agreement with those of experimental data which provided by Subramanian et al. [7]. Using the B3LYP approach with a variety of basis sets $(6-31 \mathrm{G}, 6-$ $31++\mathrm{G}, 6-31 \mathrm{G}^{* *}, 6-31++\mathrm{G}^{* *}, 6-311 \mathrm{G}, 6-311++\mathrm{G}, 6-$ $311 \mathrm{G}^{* *}$, and $\left.6-311++\mathrm{G}^{* *}\right)$, the computed values of bond angles are only less than $1 \%$ compared to the experimental results [7]. A similar trend may be observed in the case of the dihedral angles of $\mathrm{C}_{13} \mathrm{H}_{13} \mathrm{~N}_{3} \mathrm{O}_{2}$ cluster model. The values of dihedral angles obtained are very close to the experimental values, which are only $0.1 \%$ different with those of experimental data [7].

The total energies and HOMO-LUMO gaps obtained at B3LYP level of theory, respectively are presented in Table 2. The table shows that the calculated total energies of the $\mathrm{C}_{13} \mathrm{H}_{13} \mathrm{~N}_{3} \mathrm{O}_{2}$ cluster fall in the range $-22248.10 \mathrm{eV}$ to $-22261.01 \mathrm{eV}$. By DFT calculations using Gaussian 09 software program, it can be observed from the table that as the zero energy is chosen to be corresponding to that of the $6-311++\mathrm{G}^{* *}$ basis set $(-22261.01 \mathrm{eV})$, the calculated total energy values of the $6-31 \mathrm{G}, 6-31++\mathrm{G}, 6$ $31 \mathrm{G}^{* *}, 6-31++\mathrm{G}^{* *}, 6-311 \mathrm{G}, 6-311 \mathrm{G}^{* *}$, and 6$311++\mathrm{G}^{* *}$ basis sets, respectively are only $0.01 \%-$ $0.06 \%$ higher than the basis set of $6-311++\mathrm{G}^{* *}$. In Table 2 , the HOMO-LUMO energy gaps of $\mathrm{C}_{13} \mathrm{H}_{13} \mathrm{~N}_{3} \mathrm{O}_{2}$ cluster are also reported. According to the data in the table, the HOMO-LUMO energy gap values are found in the range of $4.39 \mathrm{eV}-4.47 \mathrm{eV}$ using B3LYP method with a variety of basis sets $\left(6-31 \mathrm{G}, 6-31++\mathrm{G}, 6-31 \mathrm{G}^{* *}, 6-31++\mathrm{G}^{* *}\right.$, $6-311 \mathrm{G}, 6-311++\mathrm{G}, 6-311 \mathrm{G}^{* *}$, and $\left.6-311++\mathrm{G}^{* *}\right)$. In addition, it can also been seen that the computed values obtained are close to each other. 
Table 2. Calculated total and frontier molecular orbital energies (eV) of $\mathrm{C} 13 \mathrm{H} 13 \mathrm{~N} 3 \mathrm{O} 2$ cluster

\begin{tabular}{|c|c|c|c|c|c|c|c|c|}
\hline & 6-31G & $6-31++G$ & $6-31 G * *$ & $6-31++G^{* *}$ & 6-311G & $6-311++G$ & 6-311G** & $6-311++G^{* *}$ \\
\hline Total energy & -22248.10 & -22248.88 & -22255.59 & -22256.34 & -22253.34 & -22253.71 & -22260.65 & -22261.01 \\
\hline HOMO & -6.52 & -6.81 & -6.39 & -6.70 & -6.74 & -6.84 & -6.61 & -6.74 \\
\hline LUMO & -2.10 & -2.42 & -1.93 & -2.29 & -2.31 & -2.43 & -2.15 & -2.32 \\
\hline $\begin{array}{c}\text { HOMO-LUMO } \\
\text { gap }\end{array}$ & 4.43 & 4.39 & 4.47 & 4.42 & 4.43 & 4.41 & 4.46 & 4.43 \\
\hline
\end{tabular}

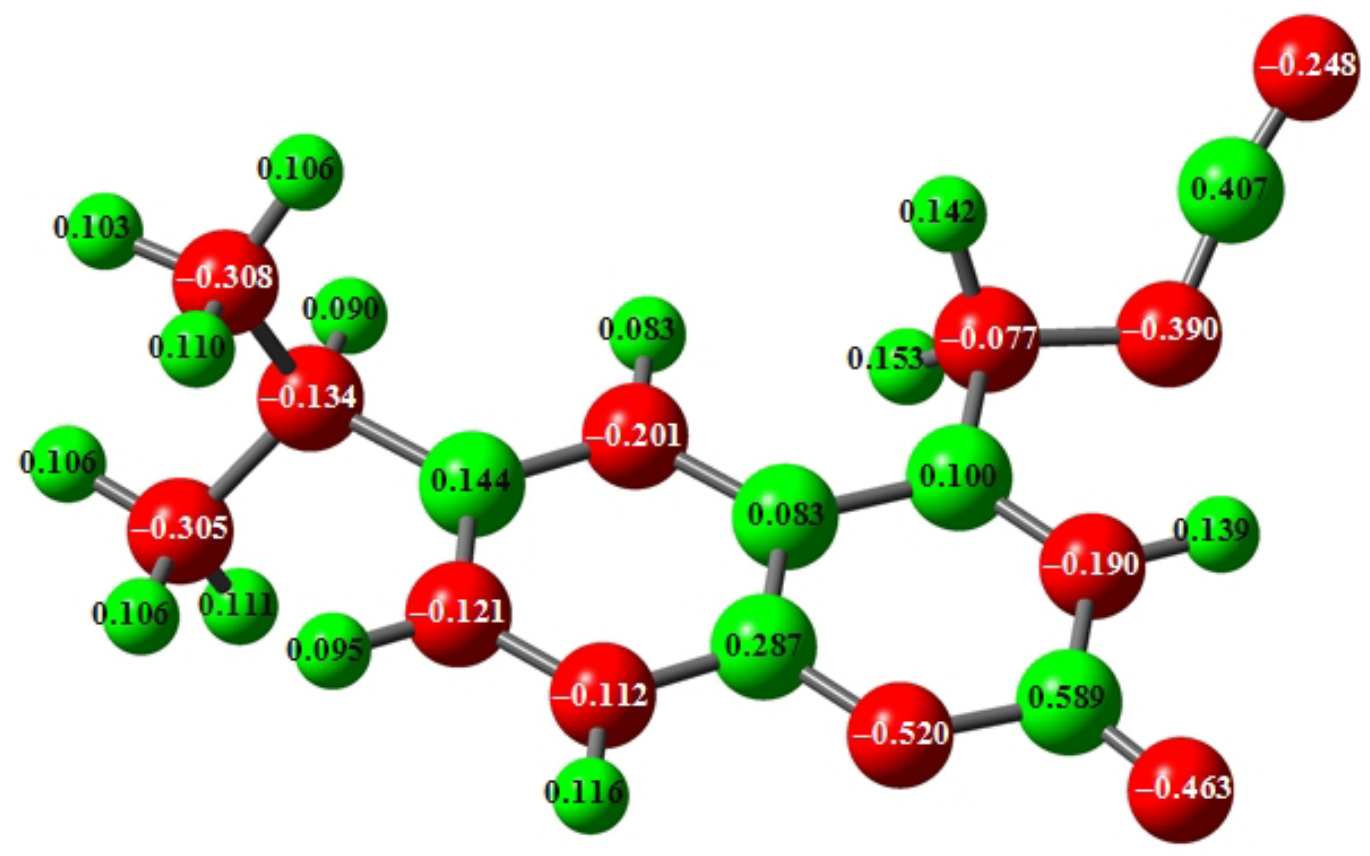

Fig. 2. The atomic charges used for the optimized molecular geometry of $\mathrm{C} 13 \mathrm{H} 13 \mathrm{~N} 3 \mathrm{O} 2$ cluster at the B3LYP/6-31G** level of theory

Fig. 2 depicts the atomic charge distributions of $\mathrm{C}_{13} \mathrm{H}_{13} \mathrm{~N}_{3} \mathrm{O}_{2}$ cluster using the Mulliken Population Analysis (MPA) at B3LYP/6-31G** level of theory. The calculation results show that the highest charge is determined to be about +0.59 for the oxygen-attached carbon, $\mathrm{C}_{2}$ atom. For both oxygen, $\mathrm{O}_{1}$ and $\mathrm{O}_{2}$ atoms, the computed charges are then determined to be about -0.52 and -0.46 , respectively. Furthermore, $\mathrm{N}_{1}$ and $\mathrm{N}_{3}$ atoms become negatively charged, with the corresponding values of charges about -0.39 and -0.25 , whereas the computed charge obtained on $\mathrm{N}_{2}$ atom is about +0.41 .

\section{Summary}

In this reported, all calculations were performed using the Gaussian 09 program package. For the geometric parameters of $\mathrm{C}_{13} \mathrm{H}_{13} \mathrm{~N}_{3} \mathrm{O}_{2}$ cluster, the calculated results obtained are consistent with the experimental data. Using B3LYP method with a variety of basis sets, the computed energies obtained are very close to each other. In addition, the charges on the oxygen-attached carbon, $\mathrm{C}_{2}$ atom was also calculated to be about +0.59 , while the charge on $\mathrm{O}_{1}$ and $\mathrm{O}_{2}$ atoms are about -0.52 and -0.46 , respectively at B3LYP/6-31G** level of theory. Further investigations are currently being carried out to study the effects of cluster size on $\mathrm{C}_{13} \mathrm{H}_{13} \mathrm{~N}_{3} \mathrm{O}_{2}$ molecular system.

\section{References}

1. A. Kathuria, S. Jalal, R. Tiwari, A.N. Shirazi, S. Gupta, S. Kumar, K. Parang and S.K. Sharma: Chem. \& Bio Interface. 1(2) (2011), p. 279.

2. B.F. Abdel-Wahab, H.A. Mohamed and A.A. Farhat: Org. Commun. 7(1) (2014), p. 1.

3. D. Nagaraja, N.R. Patil, R.A. Kusanur, H.D. Patil and R.M. Melavanki: Int. J. Life Sci. \& Pharma Research 3(1) (2014), p. L54.

4. I. Singh, H. Kaur, S. Kumar, Ar. Kumar, S. Lata and A. Kumar: Int. J. ChemTech Research 2(3) (2010), p. 1745.

5. M. Alipour, M. Khoobi, A. Foroumadi, H. Nadri, A. Moradi, A. Sakhtemah, M. Ghandi and A. Shafiee: Bioorganic \& Medicinal Chem. 20 (2012), p. 7214. 
6. M.K. Subramanian, P.M. Anbarasan and S. Manimegalai: Pramana J. Phys. 74(5) (2010), p. 845.

7. M.S. Krishnamurthy, N.S. Begum, D. Shamala and K. Shivashankar: Acta Cryst. E 71 (2015), p. o227.

8. S.V.Dekic, V.S. Dekic, B. Vucic, B.R. Dekic and M.S. Dekic: Facta Universitatis Series: Phys., Chem. and Tech. 5(1) (2007), p. 85.

9. P.L. Toh, S. Sulaiman and M.I. Mohamed-Ibrahim: Advanced Materials Research 630 (2013). p. 418.

10. P.L. Toh, S. Sulaiman, M.I. Mohamed-Ibrahim and L.S. Ang: Applied Mechanics and Materials 749 (2015). p. 134.

11. M.J. Frisch, G.W. Trucks, H.B. Schlegel, G.E. Scuseria, M.A. Robb, J.R. Cheeseman, G. Scalmani, V. Barone, B. Mennucci, G. A. Petersson, H. Nakatsuji, M. Caricato, X. Li, H.P. Hratchian, A.F.
Izmaylov, J. Bloino, G. Zheng, J.L. Sonnenberg, M. Hada, M. Ehara, K. Toyota, R. Fukuda, J. Hasegawa, M. Ishida, T. Nakajima, Y. Honda, O. Kitao, H. Nakai, T. Vreven, J.A. Montgomery, Jr., J.E. Peralta, F. Ogliaro, M. Bearpark, J.J. Heyd, E. Brothers, K.N. Kudin, V.N. Staroverov, R. Kobayashi, J. Normand, K. Raghavachari, A. Rendell, J.C. Burant, S.S. Iyengar, J. Tomasi, M. Cossi, N. Rega, J.M. Millam, M. Klene, J.E. Knox, J.B. Cross, V. Bakken, C. Adamo, J. Jaramillo, R. Gomperts, R.E. Stratmann, O. Yazyev, A.J. Austin, R. Cammi, C. Pomelli, J.W. Ochterski, R.L. Martin, K. Morokuma, V.G. Zakrzewski, G.A. Voth, P. Salvador, J.J. Dannenberg, S. Dapprich, A.D. Daniels, Ö. Farkas, J.B. Foresman, J.V. Ortiz, J. Cioslowski and D.J. Fox, Gaussian 09, Revision D.01, Gaussian, Inc. (2009). 